\title{
UIT HET BUITENLAND.
}

\author{
door Drs L. J. M. Roozen
}

\section{Canada: Enkele verklaringen van Canadese Accountants}

J. D. Campbell C.A. levert in ,the Canadian Chartered Accountant" van Januari 1951 belangwekkend commentaar bij enkele door hem aangehaalde verklaringen van Canadese accountants.

In de eerste plaats vermeldt Campbell drie verklaringen, waarin mededeling wordt gemaakt van het steunen op de interne controble resp. de interne accountantscontrôle.

1. „We made a general review of the accounting methods ..........., reviewed returns from branches certified by branch officials and examined or tested accounting records and other supporting evidence to the extent we deemed appropriate, but we did not make a detailed audit of transactions."

2. „Our examination included such tests ........ and such other procedures as we considered appropriate. The accounts of other subsidiary companies were examined by the internal auditors of the (parent) company."

3.,$\ldots . . . . .$. We made a general review of the accounting methods without making a detailed audit, ......... examined or tested the accounting records of the head office ......... and reviewed the reports furnished by the company's staff auditor on his examination of the records of the remaining (niet de voornaamste R.) branches."

Campbell stelt bij deze drie tirades enkele vragen, welke op het volgende neerkomen.

a. Kan de vermelding van de concrete wijze waarop de accountant tot zijn oordeel is gekomen, nog enige waarde toevoegen aan zijn verklaring, die zonder voorbehoud is?

b. Houdt die vermelding in, dat de accountant eigenlijk bedoelt een voorbehoud te maken?

c. Mag de accountant volstaan met kennis te nemen van een certificaat van een verantwoordelijk beamte van het bedrijf, als hij zelf in staat is de betrokken posten te verifiëren?

Voorts haalt Campbell de volgende verklaring aan.

,We have examined the books and accounts of Ltd. We have verified the cash in banks and the investment securities and the revenues received therefrom. We have obtained all the information and explanations required and in our opinion the ......... balance sheet and profit and loss account ........ exhibit a true and correct view .......... according to the best of our information and the explanations given to us and as shown by the books of the company".

Campbell vraagt zich bij deze verklaring af, of de accountant zich heeft beperkt tot de verificatie van de met name genoemde posten $(20 \%$ der activa) en hij vervolgt: "What implications would the shareholder be entitled to draw from the statement?" 
De schrijver concludeert, dat een zeker toezicht op de accountantsverklaringen door de eigen beroepsorganisatie of door een lichaam als de S.E.C. in de Verenigde Staten, wenselijk is.

Engeland: Accountantsverklaringen ten behoeve van Commissionnairs in Effecten.

"Accountancy", het orgaan van de Society of Incorporated Accountants and Auditors, meldt ${ }^{1}$ ), dat voor de Bank of England thans een jaarlijkse accountantsverklaring wordt gevraagd van commissionnairs in effecten (Stock Market Jobbers). Deze handelaren ontvangen bijzondere tegemoetkomingen van de Bank ,,for claering transfers in and out of government stocks through the registers". "Two small failures which occured in the market earlier this year no doubt impelled the bank's action", aldus Accountancy.

Het bericht luidt verder: ${ }^{2}$ )

.The English Stock Exchange Council has for some time been considering the proposal that all its members should furnish the council with certificates of their financial position prepared by independent accountants. This is a logical and desirable outcome of the recent creation of a fund for compensating members of the public against loss through failure of stock exchange firms.

The auditor's certificate now required of jobbers will read:

"We report that we have examined the books ......... for the year ended ........ and that in our opinion proper books of account have been kept by the firm, so far as appears from our examination of these books. We have examined the firm's balance sheet and certify that it is in accordance with those books. We have verified the securities, balances with bankers and bank and market loanshown in the said balance- sheet, but have not otherwise verified the assets or liabilities, nor vouched the transactions.

We report that on the basis of such balance-sheet the tanglible assets of the firm exceeded its liabilities as at ........."

Men zal zich herinneren, dat Prof. Dr Th. Limperg Jr in het Handelsblad van 26 en 27 Januari 1940 een beschouwing wijdde aan een soortgelijke actie van de Vereniging voor de Effectenhandel ${ }^{3}$ ), waarbij hij tot de conclusie kwam, dat een accountantscontrōle ten behoeve van het maatschappelijk verkeer in het effectenbedrijf niet mogelijk is om de volgende redenen.

a. Het verband tussen in- en uitgang van waarden wordt hier gemist.

b. Het persoonlijke verkeer tussen de eigenaar (eigenaren) van het bedrijf en de cliënten is regel.

c. Het hulpmiddel van de interne contrōle ontbreekt, omdat het aantal personen in het bedrijf klein is.

De openbare accountant kan hier dus, naar Limperg heeft aangetoond, geen functie vervullen. Des te opmerkelijker is, dat de English Stock

1) Zie Journal of Accountancy, Juni 1951.

2) Cursivering van mij (R.).

3) "Accountanscontrôle in het effectenbedrijf".

m a b blz. 212 
Exchange Council uitdrukkelijk om een verklaring vraagt van „independent accountants".

Beschouwt men echter de voorgeschreven text van deze verklaring, dan vraagt men zich in gemoede af, welke zekerheid deze kan geven aan het publiek ,against loss through failure of stock exchange firms". $\mathrm{E}_{\mathrm{r}}$ is immers geen sprake van een volkomen contrôle en met name biedt de verklaring geen waarborg tegen, ,het gevaar voor het onopgemerkt blijven van vergrijpen en tekorten (schuilende) in het bestaan van schulden en verplichtingen in geld of in stukken, welke niet in de boeken zijn vermeld." 4 )

4) Aldus Limperg in het aangehaalde artikel. 